$\begin{array}{ll}\begin{array}{l}\text { Pike strike } \\ \text { Alaska's salmon loss } \\ \text { blamed on predator } \\ \text { invasion } \\ p 907\end{array} & \begin{array}{l}\text { Vive la révolution } \\ \text { Fench biomedical } \\ \text { reforms pledge cash } \\ \text { for partnerships } \\ \text { p908 }\end{array}\end{array}$

\title{
Central Europe braced for tide of pollution in flood aftermath
}

\section{Quirin Schiermeier, Munich}

The flood waters of the River Elbe in central Europe are in retreat, but a new threat has emerged - dioxins, mercury and bacteria in the sludge carried by the waters.

The Elbe has been receding since 16 August, and sludge clearing is now under way in the Czech Republic and eastern Germany. At the same time, scientists in the region are carefully monitoring the toxins and risk of disease left in the flood's wake.

One major potential source of contamination is Spolana, a chemical plant in Neratovice in the Czech Republic that was submerged until last week. Several disused buildings at the facility are contaminated with dioxins, used in the 1960s to produce a component of the defoliant Agent Orange. The plant, which now makes chlorine-based products such as polyvinyl chloride, also has stores of mercury.

German environment minister Jürgen Trittin and his Czech counterpart Libor Ambrozek say that any toxins in the river would have been diluted below dangerous levels. Preliminary analysis of water from around the plant and at Dresden, 120 kilometres down-river, give no cause for alarm, they say.

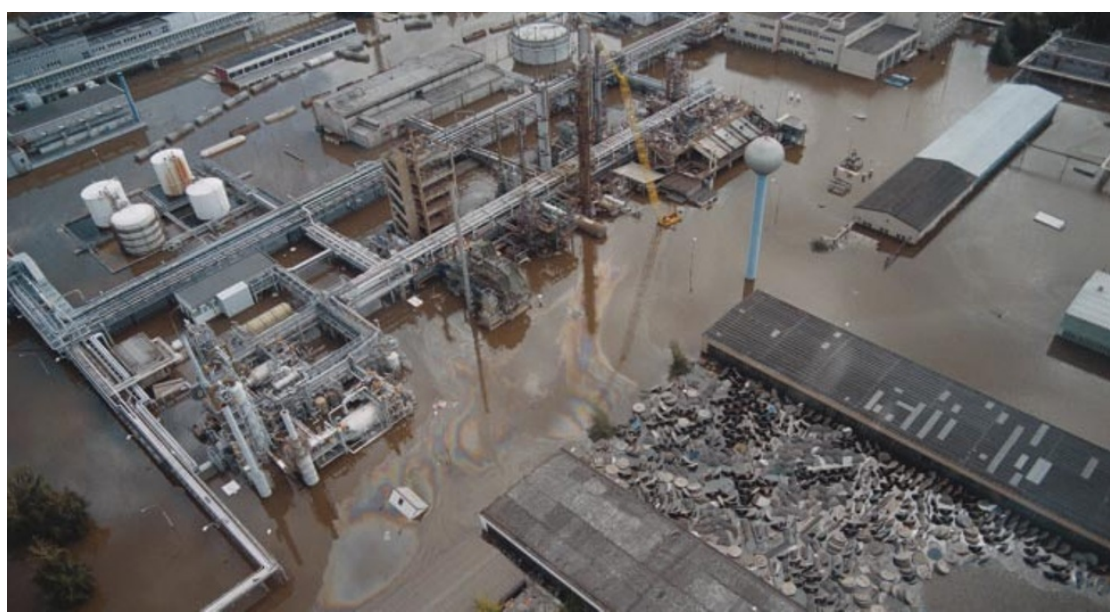

Flooding at the Spolana chemical plant has raised concerns over dioxin and mercury contamination.

But Manuel Fernandez, a chemist with the environmental group Greenpeace, says that the buildings used in the 1960s were not properly protected against floods. He adds that Czech police attempted to stop his colleagues from gathering samples near the plant, and that the authorities may try to play

\section{Web extends to bottom of the world}

David Adam, London

Proof has arrived - if any were needed that there's no escape from technology. The electronic superhighway is about to reach the ends of the Earth, when the US National Science Foundation (NSF) lays a high-speed fibre-optic cable to the South Pole.

The NSF wants to provide its research base at the pole with continuous electronic communications. It has asked Denver-based Raytheon Polar Services to investigate the practicalities of running a cable across the ice from another, larger research station, over 1,000 miles away.

“This is something we've wanted to do for a while and a feasibility study is being carried out, but it's still very early days," says Peter West, an NSF spokesman.

Polar researchers already have access to e-mail and the Internet, but only for a few hours a day. The base is the only permanently inhabited place on Earth that lacks a clear line of sight to communications satellites. It relies on intermittent contact with ageing satellites that have drifted from their orbits.

As well as giving 24-hour access to sports results, the link will allow researchers around the world to monitor remote experiments. The South Pole is popular with physicists because the compressed ice is transparent and contains few air bubbles, helping them to spot the faint light emitted from neutrinoparticle interactions. Astronomers like it because it offers 'continuous astronomical darkness' — better known as night — for several months of the year, and geologists are interested in the micrometeorites strewn across the Antarctic tundra. down the true degree of contamination.

But samples taken 300 kilometres downriver at Magdeburg in Germany are being analysed at the German Federal Institute of Hydrology in Koblenz, and initial results show no sign of dioxins. Institute staff are warning that the contamination may not have reached the site when the samples were taken, however.

The tests did find a large increase in levels of arsenic and lead, probably from slag heaps and waste deposits. The Elbe has also flooded hundreds of sewage plants and picked up many animal carcasses. Toxic substances that lay hidden beneath the riverbed may also have been disturbed, says Volkhard Wetzel, head of the Koblenz institute.

The water may also be spreading bacteria such as Salmonella. "There is no reason for panic, but we are scrutinizing the situation," says Axel Hofmann, a medical microbiologist at the Saxonian Institute for Health and Veterinary Medicine in Leipzig. Thousands of inhabitants of Prague and Dresden have been vaccinated against hepatitis $A$, which can be spread by faeces leaking into drinking water.

Dioxin contamination of the Elbe may also hamper efforts to tackle pollution from various industries during the communist era. Ironically, thousands dived into the Elbe in Dresden only last month to mark its recovery from pollution. 